\title{
PENGARUH PENGGUNAAN MEDIA PEMBELAJARAN AUDIO VISUAL ANIMASI TERHADAP HASIL BELAJAR SUBTEMA BENDA TUNGGAL DAN CAMPURAN
}

\author{
Lina Novita ${ }^{1)}$ \\ Pendidikan Guru Sekolah Dasar, Universitas Pakuan Bogor \\ linovtaz@gmail.com \\ Anggun Novianty ${ }^{2)}$ \\ Pendidikan Guru Sekolah Dasar, Universitas Pakuan Bogor \\ anggunnovianty@gmail.com
}

\begin{abstract}
Abstrak
Penelitian ini merupakan jenis penelitian kuantitatif dengan pendekatan eksperimen quasi yang terdiri dari media animasi sebagai variabel bebas dan hasil belajar sebagai variabel terikat. Tujuan penelitian ini untuk mengetahui pengaruh dari penggunaan media pembelajarn audio visual animasi terhadap hasil belajar subtema benda tunggal dan campuran. Populasi dalam penelitian ini adalah siswa kelas VA dan VB Sekolah Dasar Negeri Leuwiliang 01 Kecamatan Leuwiliang Kabupaten Bogor. Instrumen yang digunakan berupa tes pilihan ganda sebanyak 27 butir soal dengan koefisien reliabilitasnya sebesar 0,770 . Teknik analisis data yang digunakan yaitu uji prasyarat analisis yang meliputi uji normalitas, uji homogenitas dan uji hipotesis penelitian dengan uji t, maka terdapat pengaruh dari penggunaan media animasi terhadap hasil belajar subtema benda tunggal dan campuran diperoleh $N$-Gain 70 dengan ketuntasan hasil belajar $100 \%$ sedangkan kelompok kelas kontrol diperoleh $N$-Gain 52 dengan ketuntasan hasil belajar 80,5\%. hasil pengujian hipotesis pada kelompok kelas eksperimen dan kelas kontrol meyatakan bahwa $\mathrm{H}_{0}$ ditolak dan $\mathrm{H}_{\mathrm{a}}$ diterima karena $t_{\text {hitung }}>t_{\text {tabel }}(4,6436>1,6675)$. Berdasarkan hasil penelitian dapat disimpulkan bahwa penggunaan media animasi memberikan pengaruh terhadap hasil belajar subtema benda tunggal dan campuran di kelas $\mathrm{V}$ Sekolah Dasar Negeri Leuwiliang 01 Kecamatan Leuwiliang Kabupaten Bogor Semester Genap Tahun Pelajaran 2018/2019.
\end{abstract}

Kata kunci : hasil belajar, media animasi

\begin{abstract}
This research is a type of quantitative research with a quasi experimental approach consisting of animated media as independent variables and learning outcomes as dependent variables. The purpose of this study was to determine the effect of the use of audio-visual animation learning media on the learning outcomes of single and mixed object sub-themes. the population in this study were students of VA and VB classes. Leuwiliang 01 Public Elementary School Leuwiliang District, Bogor Regency. The instrument used in the form of multiple choice tests as many as 27 items with a reliability coefficient of 0.770 . The data analysis technique used is the analysis prerequisite test which includes normality test, homogeneity test and research hypothesis test with t test, then there is an influence of the use of animation media on learning outcomes of single objects and mixtures subtypes obtained by $\mathrm{N}$-Gain 70 with $100 \%$ completeness of learning outcomes while the control class group obtained n-gain 52 with completeness of learning outcomes $80.5 \%$. Hypothesis testing results in the experimental class and control class states that $H_{0}$ is rejected and $H_{a}$ is accepted because $t_{\text {count }}>t_{\text {table }}(4.6436>1.6675)$. Based on the results of the study it can be concluded that the use of animation media has an influence on the learning outcomes of single and mixed objects sub-themes in class $V$ of Leuwiliang 01 Public Elementary School in Leuwiliang District, Bogor Regency, even semester 2018/2019 academic year.
\end{abstract}

Keywords: learning outcomes, animation media 


\section{A. PENDAHULUAN}

Belajar merupakan perubahan pada individu yang menyatakan sebgai suatu pola baru dari reaksi berupa kecakapan, sikap, tingkah laku, kabiasaan dan kepribadian. Seseorang dikatakan belajar ketika terjadi perubahan tingkah laku sebagai akibat dari pengalaman, maka berusaha untuk mencapai perubahan tingkah laku tersebut disebut dengan hasil belajar.

Hasil belajar dapat dilakukan sebagai usaha dalam mengubah prilaku dari yang tidak tahu menjadi tahu. Baik buruknya hasil belajar berkaitan dengan pengetahuan yang dipelajarinya. Pencapaian hasil belajar mengarah pada nilai yang didapatkan oleh siswa. Namun pada keyatannya hasuk belajar siswa yang mendapatkan nilai belum sesuai dengan standar yang ditetapkan sekolah.

Kondisi tersebut dibuktikan dari data hasil observasi di klas VA dan VB di Sekolah Dasar Negeri Leuwiliang 01 semester genap tahun pelajaran 2018/2019. Diketahui bahwa Penilaian Tengah Semester (PTS) dari 75 siswa yang mencapai nilai di atas KKM sebanyak 47 siswa atau 62,7\% dan 28 siswa atau $37,3 \%$ siswa masih di bawah KKM, hal yang menjadi penyebab dari banyaknya siswa yang masih di bawah KKM yaitu siswa masih mendapatkan perlakuan model, metode dan media pembelajaran yang belum bervariatif. Hal tersebut mengakibatkan siswa menjadi jenuh ketika belajar karena kegiatan belajar mengajar menjadi monoton.

Permasalahan di atas dapat dirumuskan masalah dalam penelitian ini yaitu, apakah terdapat pengaruh penggunaan media pembelajaran audio visual animasi terhadap hasil belaajr subtema benda tunggal dan campuran. Dengan demikian, maka tujuan penelitian ini yaitu untuk mengetahui pengaruh penggunaan media pembelajaran audio visual animasi terhadap hasil belajar subtema benda tunggal dan campuran.

Penggunaan media pembelajaran audio visual animasi dapat diketahui dari hasil penelitian Viviantini (2015), yang menemukan hasil penelitian bahwa media pembelajaran auido visual bepengaruh terhadap minat dan hasil belajar siswa. Kemudian penelitian mengenai media audio visual animasi diteliti oleh Munawaroh (2015), hasil penelitiannya yaitu media animasi berpengaruh terhadap hasil belajar siswa.

Lalu selanjutnya peneltian mengenai pengaruh meia animasi terhadap hasil belajar dapat dilihat dari hasil penelitian Yulia dan Arifin (2016) yang menemukan hasil penelitian bahwa media animasi berpengaruh secara signifikan, hal tersebut ditunujukkan dengan hasil pengujian hipotesis menerima hipotesis alternatif $\left(\mathrm{H}_{\mathrm{a}}\right)$ dan hipotesis nol ditolak $\left(\mathrm{H}_{0}\right)$.

Penelitian serupa juga dapat diketahui dari hasil penelitian Sukiyasa dan Sukoco (2013) dapat dilihat dari hasil penelitiannya bahwa media animasi berpengaruh signifikan terhadap hasil belajar ditunjukkan dengan hasil pembelajaranpembelajaran menggunakan media animasi lebih tinggi dari hasl belajar siswa yang diajarkan menggunakan media powerpoint.

Hasil belajar merupakan perubahan-perubahan yang terjadi pada diri siswa. Dalam hal ini Naswawi berpenapat dalam Susanto (2013:5) menyatakan bahwa hasil belajar merupakan tingkat keberhasilan siswa dalam mempelajari materi pelajaran di sekolah yang dinyatakan dalam skor yang diperoleh dari hasil tes. Senada dengan Nawawi dalam Susanto, Yulia dan Arifin (2016:37) berpendapat bahwa hasil belajar merupakan suatu bukti keberhasilan seseorang dalam mempelajari materi pembelajaran di sekolah yang dinyatakan dalam bentuk nilai yang diperoleh dari hasil belajar yaitu tes. Adapun pendapat senada mengenai hasil belajar disampaikan oleh Sukiyasa dan Sukoco bahwa hasil belajar merupakan dampak dari segala proses memperoleh pengetahuan, hasil dari latihan, hasil dari proses perubahan tingkah laku yang dapat diukur baik melalui tes perilaku, tes kemampuan kognitif, maupun tes psikomotorik.

Hasil belajar juga memiliki berbagai macam jenisnya, menurut Usman dalam Jihad dan Haris (2012:16) hasil belajar dibagi menjadi tiga kelompok yaitu (1) domain kognitif, (2) domain afektif dan (3) domain psikomotorik.

Adapun faktor-faktor yang mempengaruhi hasil belajar menurut Slameto (2013:54) yaitu:

1. Faktor internal, merupakan faktor yang bersumber dari dalam diri siswa yang mempengaruhi hasil belajarnya. Faktor internal meliputi kecerdasan, minat, motivasi belajar, ketekunan, sikap, kebiasaan belajar, serta kondisi fisik dan kesehatan. 
2. Faktor eksternal, merupakan faktor yang bersumber dari luar diri siswa. Diantaranya keluarga, sekolah dan masyarakat.

Berdasarkan teori di atas, maka dapat disintesiskan bahwa hasil belajar merupakan perubahan tingkah laku atau dampak dari siswa setelah mendapatkan pengelaman-pengalaman belajar, hasil belajar dapat diukur menggunakan alat berupa tes perilaku, tes kognitif maupun tes psikomotrik.

Hasil belajar akan baik apabila materi pembelajaran disampaikan menggunakan bantuan media pembelajaran. Menurut Gagne dalam Sadiman, dkk., (2014:6) berpendapat bahwa media merupakan salah satu komponen komunikasi ke komunikan. Media merupakan berbagai jenis komponen dalam lingkungan siswa yang dapat merangsangnya untuk belajar sehingga pembelajaran menjadi lebih bermakna. Senada dengan Gagne dalam Sadiman (2014) Yulia dan Arifin (2016:34) berpendapat bahwa media pembelajaran merupakan segala sesuatu yang dapat menyalurkan pesan, dapat merangsang fikirn, perasaan dan kemampuan peserta didik sehingga dapat mendorong terciptanya proses belajar pada diri peserta didik guna mencapai tujuan pembelajaran. Adapun pendapat senada mengenai media pembelajaran disampaikan oleh Adam (2015) menurutnya media pembelajaran merupakan segala sesuatu baik secara fisik maupun teknis dalam proses pembelajaran yang dapat membantu guru untuk mempermudah dalam menyampaikan materi pelajaran kepada siswa sehingga memudahkan pencapaian tujuan pembelajaran yang telah dirumuskan.

Adapun manfaat media pembelajaran menurut Sanjaya (2012:70) yaitu: 1) menangkap suatu objek atau peristiwa-peristiwa tertentu; 2) memanipulasi keadaan, peristiwa atau keadaan tertentu; 3) menambah gairah dan motivasi belajar siswa.

Selanjutnya selain memiliki banyak manfaat, media pembelajaran juga memiliki beberapa karakteristik menurut Daryanto (2013:19) yaitu (1) media grafis (2) media audio (3) media proyeksi diam (4) media film (5) media audio visual diam

Media animasi bisa disebut juga dengan media film. Pengertian media animasi juga disampaikan oleh Susilana dan Riyana bahwa film disebut juga gambar hidup yaitu serangkaian gambar diam yang meluncur secara cepat dan diproyeksikan sehingga menimbulkan kesan hidup dan bergerak. Adapun Johari (2014:10) berpendapat bahwa media animasi merupakan pergerakan sebuah objek atau gambar sehingga dapat berubah posisi. Selain pergerakan, objek dapat mengalami perubahan bentuk dan warna. Media animasi dalam pembelajaran berfungsi untuk menarik perhatian siswa dalam belajar sehingga dapat memberi pemahaman yang lebih cepat. Senada dengan Susilana, Riyana dan Johari, pengertian media animasi pun disampaikan oleh Yulia dan Arifin (2016) berpendapat bahwa media film secara sederhana dapat didefinisikan sebagai alat bantu dalam pembelajaran yang berupa sebuah film, yang berfungsi sebgai cerita yang dituturkan kepada penonton atau peserta didik melalui rangkaian gambar bergerak dan suara.

Di bawah ini terdapat kelebihan media animasi menurut Johari (2014:9) diantaranya: 1) memperkecil ukuran objek yang secara fisik cukup besar dan sebaliknya; 2) memiliki lebih dari satu media yang konvergen, misalnya menghubungkan unsur audio visual; 3) memudahkan guru untuk menyajikan informasi mengenai proses yang cukup kompleks; 4) menarik perhatian siswa sehingga meningkatkan motivasi belajarnya; 5) bersifat interaktif dalam arti memiliki kemampuan untuk mengakomodasi respon pengguna; 6) bersifat mandiri, dalam arti memberikan kemudahan dan kelengkapan isis sedemikian rupa sehingga pengguna bisa menggunakan tanpa bimbingan orang lain.

Lalu selanjutnya ada kekurangan mengani media animasi, yaitu: 1) memerlukan biaya yang cukup mahal; 2) memerlukan software khusus untuk membukanya; 3) memerlukan kreativitas dan keterampilan yang cukup memadai untuk mendesain animasi yang dapat secara efektif digunakan sebagai media pembelajaran; 4) tidak dapat menggambarkan realitas seperti video atau fotografi.

Berdasarkan teori di atas dapat disintesiskan bahwa media animasi merupakan serangkaian gambar yang dapat bergerak lalu berpindah posisi dan memiliki suara dan warna lalu dapat diproyeksikan. 


\section{B. METODOLOGI PENELITIAN}

Penelitian ini menggunakan eksperimen quasi desain dua grup. Penelitian ini dilakukan di kelas V Sekolah Dasar Negeri Leuwiliang 01 Kecamatan Leuwliang Kabupaten Bogor semester genap tahun pelajaran 2018/2019.

Populasi menurut Arikunto (2010:173) merupakan keseluruhan subjek penelitian. Populasi dalam penelitian ini adalah siswa kelas V Sekolah Dasar Negeri Leuwiliang 01 Kecamatan Leuwliang Kabupaten Bogor Semester genap tahun pelajaran 2018/2019 yang berjumlah 75 siswa yang terdiri dari 39 siswa kelas V A dan 36 siswa kelas V B. Secara kuantitatif populasi sama dengan sampel, karena penerapan pembelajaran dalam satu kelas.

Tabel 1 Rekapitulasi Hasil Uji Coba Instrumen Penelitian Hasil Belajar Subtema Benda Tunggal dan

Campuran

\begin{tabular}{|c|c|c|c|c|c|c|c|c|c|}
\hline \multirow{2}{*}{\multicolumn{2}{|c|}{ Validitas }} & \multirow{2}{*}{$\begin{array}{l}\text { Koefisien } \\
\text { Reliabilitas }\end{array}$} & \multicolumn{3}{|c|}{$\begin{array}{l}\text { Tingkat Kesukaran } \\
\text { Soal }\end{array}$} & \multicolumn{4}{|c|}{ Daya Pembeda } \\
\hline & & & $\mathrm{Md}$ & $\mathrm{Sd}$ & Sk & $\mathrm{Jl}$ & $\mathrm{Ck}$ & $\mathrm{Bk}$ & $\mathrm{Bs}$ \\
\hline Jumlah & 30 & & \multicolumn{3}{|l|}{30} & \multicolumn{4}{|l|}{30} \\
\hline Persentase & $60 \%$ & $\begin{array}{l}\text { KR-20 } \\
0,770\end{array}$ & $46,7 \%$ & $\begin{array}{l}53, \\
3 \%\end{array}$ & & $\begin{array}{l}10 \\
\%\end{array}$ & $\begin{array}{l}36, \\
7 \%\end{array}$ & $\begin{array}{l}43,3 \\
\%\end{array}$ & $\begin{array}{l}10 \\
\%\end{array}$ \\
\hline
\end{tabular}

Teknik pengumpulan data dalam penelitian ini menggunakan instrumen tes dan nontes. Instrumen tes digunakan untuk pengumpulan data mengenai hasil belajar berupa tes pilihan ganda berjumlah 50 dengan empat alternatif jawaban yang sebelumnya sudah di uji cobakan kepada kelas yang lebih tinggi dan telah menerima materi subtema benda tunggal dan campuran sebelumnya guna untuk menguji validitas dan reliabilitas butir soal. Lalu teknik pengumpulan data mengenai media animasi menggunakan angket sebanyak 50 pernyataan yang sebelumnya di uji cobakan terlebih dahulu. Instrumen nontes disusun dalam bentuk pernyataan dengan menggunakan skala dua. Instrumen hanya meminta responden untuk memilih salah satu altrernatif jawaban yang sudah disediakan. Adapun alternatif jawabannya adalah Ya dan Tidak.

Setelah mengumpulkan data-data, kemudian dilakukanlah analisis data. Adapun data yang dianalisis yaitu dua, analisis data hasil belajar dan analisis data angket.

\section{HASIL PENELITIAN}

Berdasarkan hasil uji coba instrumen penelitian yang telah dilaksanakan di kelas VI A dan VI B Sekolah Dasar Negeri Leuwiliang 01 pada Subtema Benda Tunggal dan Campuran dengan jumlah responden sebanyak 63 siswa diperoleh 30 soal yang valid dan 20 soal tidak valid. Kemudian 30 butir soal tersebut digunakan untuk menguji hasil belajar subtema benda tunggal dan campuran di kelas eksperimen dan kelas kontrol. Butir soal yang valid berjumlah 30 dan diperoleh koefisien reliabilitasnya yaitu sebesar 0,770 maka tingkat kepercayaan butir soal adalah tinggi, sehingga layak untuk digunakan dalam pengambilan data, lalu untuk instrumen nontes angket variabel media pembelajaran audio visual animasi yang terdiri dari 50 butir pernyataan yang diuji cobakan dengan hasil 29 pernyataan yang valid (58\%) dan 21 pernyataan tidak valid (42\%) dengan koefisien reliabilitasnya sebesar 0,874 dengan kriteria sangat tinggi.

Tabel 4.2 Rekapitulasi Hasil Uji Coba Instrumen Penelitian Angket Media Pembelajaran Audio Visual Animasi

\begin{tabular}{|c|c|}
\hline$K r$ & $K s$ \\
\hline 0,90 & 0,80 \\
\hline
\end{tabular}

Sumber: Widhiarso, W. (2011)

Deskripsi data hasil penelitian ini terdiri dari data variabel hasil belajar (Y) dan variabel media animasi (X) yang dideskripsikan dalam bentuk deskriptif statistik dapat di bawah ini.

Berdasarkan hasil rekapitulasi angket siswa terhadap media animasi sebanyak 35 siswa atau $97 \%$ tertarik dengan adanya media animasi pada pembelajaran subtema benda tunggal dan campuran. 
Adapun hasil penelitian mengenai tingkat kesukaran dan daya pembeda soal posttest pada kelas eksperimen dan kelas kontrol pada tabel di bawah ini.

Tabel 3 Rekapitulasi Tingkat Kesukaran Soal Kelas Eksperimen dan Kelas Kontrol

\begin{tabular}{|c|c|c|c|c|c|c|}
\hline \multirow{2}{*}{ Validitas } & \multicolumn{6}{|c|}{ Tingkat Kesukaran } \\
\cline { 2 - 7 } & \multicolumn{3}{|c|}{ Kelas Eksperimen } & \multicolumn{3}{c|}{ Kelas Kontrol } \\
\cline { 2 - 7 } & $\mathrm{Md}$ & $\mathrm{Sd}$ & $\mathrm{Sk}$ & $\mathrm{Md}$ & $\mathrm{Sd}$ & $\mathrm{Sk}$ \\
\hline Jumlah & 26 & 1 & 0 & 21 & 6 & 0 \\
\hline Persentase & $96,23 \%$ & $3,77 \%$ & 0 & $77,8 \%$ & $22,2 \%$ & 0 \\
\hline
\end{tabular}

Tabel 4 Rekapitulasi Daya Pembeda Soal Kelas Eksperimen dan Kelas Kontrol

\begin{tabular}{|c|c|c|c|c|c|c|c|c|}
\hline \multirow{3}{*}{ Validitas } & \multicolumn{8}{|c|}{ Daya Pembeda } \\
\cline { 2 - 10 } & \multicolumn{3}{|c|}{ Kelas Eksperimen } & \multicolumn{5}{c|}{ Kelas Kontrol } \\
\cline { 2 - 10 } & J1 & Ck & B & BS & Jl & CK & B & BS \\
\hline Jumlah & 22 & 4 & 1 & 0 & 21 & 5 & 1 & 0 \\
\hline Persentase & $81,5 \%$ & $14,8 \%$ & $3,70 \%$ & 0 & $77,8 \%$ & $18,5 \%$ & $3,70 \%$ & 0 \\
\hline
\end{tabular}

Selanjutnya rekapitulasi skor rata-rata hasil belajar subtema benda tunggal dan campuran kelompok kelas eksperimen dan kelompok kelas kontrol dapat dilihat pada tabel di bawah ini.

Tabel 5 Skor Rata-rata $N$-Gain

\begin{tabular}{|c|c|c|c|}
\hline \multicolumn{2}{|c|}{ Rekapitulasi Nilai } & \multicolumn{2}{|c|}{ Kelompok Kelas } \\
\cline { 3 - 4 } \multicolumn{2}{|c|}{} & $\begin{array}{c}\text { Media } \\
\text { Animasi }\end{array}$ & Konvensional \\
\hline \multirow{2}{*}{$\begin{array}{c}\text { Nilai } \\
\text { Terendah }\end{array}$} & Pretest & 41 & 33 \\
\cline { 2 - 4 } & Postest & 78 & 70 \\
\cline { 2 - 4 } & $\begin{array}{c}N- \\
\text { Gain }\end{array}$ & 41 & 9 \\
\hline Nilai & Pretest & 67 & 67 \\
\cline { 2 - 4 } Tertinggi & Postest & 100 & 96 \\
\cline { 2 - 4 } & $N-$ & 100 & 90 \\
\hline Nilai & Gain & & \\
\cline { 2 - 4 } Rata-rata & Pretest & 57 & 54,6 \\
\cline { 2 - 4 } & Postest & 88 & 76,9 \\
\cline { 2 - 4 } & $N-$ & 70,7 & 52 \\
& Gain & & \\
\hline
\end{tabular}

Berdasarkan tabel distribusi frekuensi di atas, maka grafik histogram rekapitulasi nilai hasil belajar subtema benda tunggal dan campuran dapat dilihat pada gambar di bawah ini.

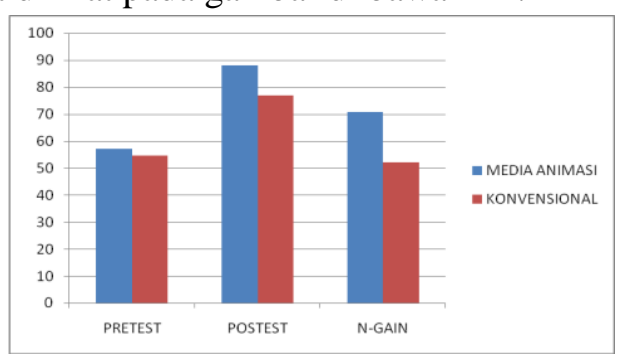

Gambar 1 Perbedaan Skor Rata-rata Hasil Belajar Kognitif Subtema Benda Tunggal dan Campuran Media Pembelajaran Audio Visual Animasi dan Media Pembelajaran Konvensional 
Uji Normalitas Galat Baku Taksiran dilakukan untuk mengetahui normal atau tidaknya suatu distribusi data, untuk mengujinya menggunakan uji Liliefors pada variabel hasil belajar (Y) dan variabel media animasi $(\mathrm{X})$ dan kelompok kelas kontrol dengan syarat jika $\mathrm{Ho}=\mathrm{L}_{\mathrm{hitung}}>\mathrm{L}_{\text {tabel}}$, berarti galat baku taksiran tidak normal dan jika $\mathrm{Ho}=\mathrm{L}_{\text {hitung }}<\mathrm{L}_{\text {tabel, }}$, berarti galat baku taksiran normal.

Berdasarkan perhitungan uji normalitas menggunakan uji Liliefors, maka ditemukan $\mathrm{L}_{\text {hitung }}=0,091$ sementara $\mathrm{L}_{\text {tabel }}=0,147$, sehingga $\mathrm{L}_{\text {hitung }}<\mathrm{L}_{\text {tabeI }}=0,091<0,147$ yang berarti harga $\mathrm{L}_{\text {hitung }}$ lebih kecil dari $\mathrm{L}_{\text {tabel }}$ maka terdistribusi normal.

Selanjutnya perhitungan uji normalitas pada kelompok kelas kontrol, maka ditemukan $\mathrm{L}_{\text {hitung }}=0,055$ sementara $\mathrm{L}_{\text {tabel }}=0,151$, sehingga $\mathrm{L}_{\text {hitung }}<\mathrm{L}_{\text {tabel }}=0,055<0,151$ yang berarti harga $\mathrm{L}_{\text {hitung }}$ lebih kecil dari $\mathrm{L}_{\mathrm{tabel}}$ maka terdistribusi normal

Pengujian homogenitas dilakukan untuk mengetahui apakah varians populasi bersifat homegen atau tidak. Pengujian homorgenitas dilakukan dengan Uji Varians (Uji Fisher). Kriteria pengujian adalah $\mathrm{F}_{\text {hitung }}<\mathrm{F}_{\text {tabel }}$ pada taraf signifikan $\alpha=0,05$

Berdasarkan hasil perhitungan uji $F_{\text {hitung }}$ sebesar 1,482 untuk sampel 68 dan taraf signifikan $\alpha(0,05)$ diperoleh Ftabel sebesar 3,98. Dimana jika $F_{\text {hitung }}<F_{\text {tabel }}$ berarti homogen dan jika $F_{\text {hitung }}>F_{\text {tabel }}$ tidak homogen.

Berdasarkan hasil perhitungan homogenitas data diperoleh nilai $F_{\text {hitung }}=1,482$ Sedangkan $F_{\text {tabel }}=3,98$ Berdasarkan kriteria $\mathrm{F}_{\text {hitung }}<\mathrm{F}_{\text {tabel }}$ hal ini berarti data homogen.

Selanjutnya perhitungan uji hipotesis penelitian. nilai $t_{\text {hitung }}$ sebesar 4,6436 dan $t_{\text {tabel }}$ sebesar 1,6675 , Berdasarkan hasil perhitungan diperoleh sebesar 4,6436 dan the sebesar 1,6675 berafti $\mathrm{H}_{0}$ ditolak dan $\mathrm{H}_{\mathrm{a}}$ diterima.

\section{PEMBAHASAN}

Berdasarkan data hasil penelitian yang telah diperoleh, diketahui skor rata-rata $N$-Gain hasil belajar subtema benda tunggal dan campuran antara dua kelas sampel penelitian. Sehingga diperoleh perbedaan ratarata $\mathrm{N}$-Gain hasil belajar subtema benda tunggal dan campuran yang signifikan antara kelas eksperimen yang menggunakan media pembelajran audio visual animasi dengan kelompok kelas kontrol yang menggunakan media pembelajaran konvensional. Berdasarkan nilai rata-rata $N$-Gain kelompok kelas eksperimen yang menggunakan media pembelajaran audio visual animasi dan kelompok kelas kontrol yang menggunakan media pembelajaran konvensional yaitu sebesar 70,7 dan 52. Hal tersebut menunjukkan adanya peningkatan hasil belajar subtema benda tunggal dan campuran dengan menggunakan media pembelajaran audio visual animasi pada kelas eksperimen lebih tinggi dibandingkan dengan hasil belajar subtema benda tunggal dan campuran pada kelompok kelas kontrol yang menggunakan media pembelajaran konvensional. Setelah dilakukan uji t nilai rata-rata $N$-gain kedua kelompok kelas tersebut diperoleh $t_{\text {hitung }}>t_{\text {tabel }}(4,6436>1,6675)$, hal ini menunjukkan adanya peningkatan hasil belajar kognitif subtema Benda Tunggal dan Campuran kelompok kelas eksperimen yang menggunakan media pembelajaran audio visual animasi yang lebh tinggi dibandingkan dengan hasil belajar kognitif subtema Benda Tunggal dan Campuran pada kelas kontrol menggunakan media pembelajaran konvensional.

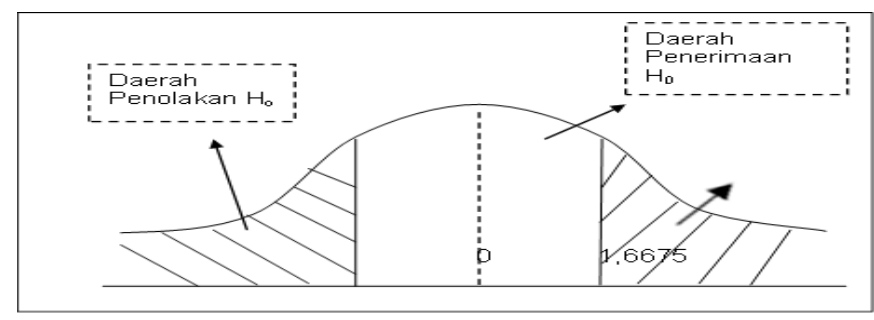

Gambar 2 Kurva Penolakan $\mathrm{H}_{0}$ 
Berdasarkan hasil penelitian yang dilakukan oleh Viviantini (2016) dalam jurnalnya yang berjudul "Pengaruh Media Pembelajaran Terhadap Minat dan Hasil Belajar Siswa Kelas VI SDN Kayumalue Ngapa" menyatakan bahwa pembelajaran menggunakan media video berpengaruh signifikan terhadap minat belajar siswa kelas VI SDN Kayumalue Ngapa. Berdasarkan data yang ada diperoleh $t_{\text {hitung }}=4,56$ dan $t_{\text {tabel }}=0,140$. Terdapat perbedaan antara kelas kontrol dan kelas yang diberi perlakuan, kelas yang diberi perlakuan sangat tertarik dengan penggunaan media pembelajaran video yang ditayangkan oleh guru. Jadi penggunaan media pembelajaran audio visual sangat berpengaruh terhadap minat dan hasil belajar siswa.

Selanjutnya penelitian mengenai penggunaan media animasi terhadap hasil belajar pernah diteliti oleh Johari, Hasan dan Rakhman, dalam hasil penelitiannya tidak terdapat perbedaan hasil belajar siswa menggunakan media animasi dibuktikan dengan hasil uji hipotesis aspek kognitif diperoleh bahwa $\mathrm{t}_{\text {hitung }}<$ $\mathrm{t}_{\text {tabel }}(0,041<1,999)$ maka $\mathrm{H}_{0}$ diterima dan $\mathrm{H}_{\mathrm{a}}$ ditolak.

Selain itu adapun penelitian yang dilakukan oleh Sukiyasa dan Sukoco (2013) hasil datanya menunjukkan terdapat pengaruh dari penggunaan media pembelajaran animasi $(\mathrm{X})$ terhadap hasil belajar siswa (Y), pengaruh tersebut dapat dilihat dari uji $t$ hasil belajardengan harga $t_{\text {hitung }}>t_{\text {tabel }}(3,279>2,000)$ yang artinya $H_{0}$ ditolak dan $\mathrm{H}_{\mathrm{a}}$ diterima, berarti hasil belajar yang diajarkan menggunakan media pembelajaran animasi lebih tinggi dari hasil belajar yang diajarkan menggunakan media pembelajaran powerpoint. Berdasarkan analisis uji Schaffle diperoleh data $\mathrm{F}_{\text {hitung }}=12,07$ dan $\mathrm{F}_{\text {tabel }}=4,00$, hal ini berarti $\mathrm{F}_{\text {hitung }}>\mathrm{F}_{\text {tabel }}$ dengan demikian dapat disimpulkan bahwa hasil belajar kelompok eksperimen lebih tinggi dari hasil belajar kelompok kontrol.

Selanjutnya penelitian mengenai pengaruh media animasi terhadap hasil belajar juga pernah diteliti oleh Yulia dan Arifin (2016) hasil penelitiannya menunjukkan bahwa media animasi berpengaruh secara signifikan terhadap hasil belajar, hal tersebut ditunjukkan oleh penghitungan uji hipotesis menerima $\mathrm{H}_{\mathrm{a}}$ dan $\mathrm{H}_{0}$ ditolak karena nilai $t_{\text {hitung }}$ lebih besar dari nilai $\mathrm{t}_{\text {tabel }}$ maka $\mathrm{H}_{\mathrm{a}}$ diterima artinya terdapat perubahan hasil belajar yang signifikan dari pengaruh media animasi.

Penelitian selanjutnya mengenai pengaruh media terhadap hasil belajar diteliti oleh Kartikasari (2016) dengan judul pengaruh penggunaan multimedia terhadap motivasi dan hasil belajar. Hasil penelitiannya menunjukkan bahwa terdapat pengaruh yang signifikansi terhadap hasil belajar yang ditunjukkan oleh perhitungn signifikansi menunjukkan $0,046<0,050$ yang artinya terdapat pengaruh yang signifikan dari media pembelajaran terhadap hasil belajar. kemudian penelitian tentang pengembangan media pembelajaran komik digital dilakukan Sukmanasa, Windiyani, dan Novita (2017) menemukan bahwa penggunaan media tersebut dapat meningkatkan hasil belajar.

Hasil penelitian dari artikel jurnal tesrebut menjelaskan bahwa penggunaan media pembelajaran memiliki oeran yang penting dalam peningkatan hasil belajar. dengan media pembelajaran hasil belajar siswa meningkat dan motivasi belajar siswa juga meningkat.

Penggunaan media pembelajaran audio visual animasi di kelas V Sekolah Dasar Negeri Leuwiliang 01 Kabupaten Bogor semester genap tahun pelajaran 2018/2019 berpengaruh positif terhadap peningkatan hasil belajar kognitif siswa subtema Benda Tunggal dan Campuran. Hal tersebut dapat dibuktikan dengan penelitian relevan yang telah dikemukakan pada Bab II, dengan menggunakan media pembelajaran audio visual animasi dapat meningkatkan hasil belajar siswa.

\section{E. SIMPULAN}

Berdasarkan hasil pengolahan data, hasil hipotesis dan pembahasan hasil penelitian, dalam penelitian ini terdapat pengaruh dari penggunaan media animasi terhadap hasil belajar subtema benda tunggal dan campuran di kelas V Sekolah Dasar Negeri Leuwiliang 01 Kecamatan Leuwiliang Kabupaten Bogor semester genap tahun pelajaran 2018/2019 dengan taraf signifikansi 5\% diperoleh thitung sebesar 4,6436 dan ttabel sebesar 1,6675 maka $\mathrm{H}_{0}$ ditolak dan $\mathrm{H}_{\mathrm{a}}$ diterima. Hal tersebut ditunujukkan dengan nilai rata-rata $N$-Gain antara kelompok kelas eksperimen lebih tinggi dari kelompok kelas kontrol yaitu sebesar 70,7 sedangan kelompok kelas kontrol sebesar 52. Lalu berdasarkan hasil respon angket siswa terhadap media animasi 
sebesar $97 \%$ siswa tertarik dengan penggunaan media animasi ketika pembelajaran subtema benda tunggal dan campuran.

\section{F. DAFTAR PUSTAKA}

Arikunto, Suharsimi. 2010. Prosedur Penelitian Suatu Pendekatan Praktik. Jakarta: Rineka Cipta

Adam, Steffi. 2015. Pemanfaatan Media Pembelajaran Berbasis Teknologi Informasi Bagi Siswa Kelas X SMA Ananda Batam. CIBS Journal, Volume 3 No 2, ISSN 2337-8794 [21 Juni 2019]

Daryanto. 2013. Media Pembelajaran Peranannya Sangat Penting Dalam Mencapai Tujuan Pembelajaran. Yogjakarta: Gava Media

Johari, Andriana. Hasan Syamsuri. Rakhman Maman. 2014. Penerapan Media Video dan Animasi Pada Materi Memvakum dan Mengisi Refrigeran Terhadap Hasil Belajar Siswa. Journal of Mechanical Engineering Education, Vol.1, No.1 [30 Oktober 2018]

Kartikasi, Galuh. 2016. Pengaruh Media Pembelajaran Berbasis Multimedia Terhadap Motivasi dan Hasil Belajar Materi Sistem Pencernaan Manusia. Dinamika Penelitian, Vol 16, No.1 [6 November 2018]

Sadiman, S. Arif, R.Rahardjo, dan Anung Haryono. 2014. Media Pendidikan Pengertian, Pengembangan, dan Pemanfaatannya. Jakarta: Pustekkom Dikbud dan PT Raja Grafindo Persada.

Slameto. 2013. Belajar dan Faktor-Faktor yang Mempengaruhinya. Jakarta: Rineka Cipta

Sukiyasa, Kadek. Sukoco. 2013. Pengaruh Media Animasi Terhadap Hasil Belajar Siswa Materi Sistem Kelistrikan Otomotif. Jurnal Pendidikan Vokasi, Vol 3 [17 Desember 2018]

Sukmanasa, Elly., Windiyani, Tustiyaya., Novita, Lina. 2017. Pengembangan Media Pembelajaran Komik Digital Pada Mata Pelajaran Ilmu Pengetahuan Sosial Bagi Siswa Kelas V Sekolah Dasar Di Kota Bogor. Jurnal JPSDUntirta. Vol.3 No.2. Tersedia pada http://jurnal.untirta.ac.id/index.php/jpsd/article/view/2138. (diakses 5 Mei 2019)

Susanto, Ahmad. 2013. Teori Belajar dan Pembelajaran di Sekolah Dasar. Jakarta: Kencana Pernamedia Group.

Wina, Sanjaya. 2012. Media Komunikasi Pembelajaran. Jakarta: Kencana PRENADAMEDIA GROUP

Widhiarso, W. 2011. SKALO: Program Analisis Skala Guttman. Program Komputer. Yogyakarta: Fakultas Psikologi Universitas Gadjah Mada.

Yulia, D. Arifin Muhammad. 2016. Pengaruh Penggunaan Media Film Animasi dalam Pembelajaran IPS Terpadu Terhadap Hasil Belajar Siswa. Historia, Volume 10 [17 Desember 2018].

Viviantini. Amran Rede. Sahrul Saehana. 2015. Pengaruh Media Video Teradap Minat dan Hasil Belajar IPA Siswa Kelas VI SDN Kayumalue Ngapa. Jurnal Sains dan Teknologi Tadulako, Volume 4 